International Journal of Social Sciences and Humanities
Available online at http://sciencescholar.us/journal/index.php/ijssh
Vol. 3 No. 1, April 2019, pages: 143 152
e-ISSN: 2550-7001, p-ISSN: 2550-701X
https://doi.org/10.29332/ijssh.v3n1.275

\title{
Model of Creative Economic Development for Micro, Small and Medium-sized Culinary Industries in Kupang City Indonesia
}

\author{
Maria C. B. Manteiro ${ }^{a}$, Enos Kabu ${ }^{b}$
}

Article history: Received 27 August 2018, Accepted: 31 December 2018, Published: 25 April 2019

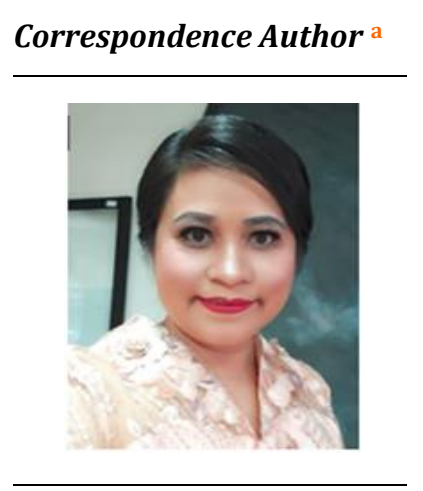

Keywords

cash flow model; creative economy; culinary industries; development model; MSMEs;

\begin{abstract}
An effort which can be conducted by the local government of Kupang city, Indonesia, to maintain its economic growth is by optimizing the role of creative industries of micro, small and medium-sized enterprises (MSMEs). One of the well-developed MSMEs in Kupang city is a culinary business. Interestingly, almost $70 \%$ of the culinary industry in the city is dominated by menus from outside rather than maintaining a typical menu of East Nusa Tenggara province which is processed creatively. The business development model of this industry tends to be partial, not integrated yet with policymakers, and other businesses, such as travel agencies and mass media. The purpose of this study was to identify and map the existence of the culinary business and to find out the model of developing a creative economy based culinary business in Kupang city, Indonesia. The object of this research was MSMEs actors who run business in the culinary industry in the city. Data were collected using observation, indepth interviews, documentation, and library studies. The sample was determined using a purposive technique, which is taken based on the consideration of the characteristics and the uniqueness of the business, that showing nature in a creative economy, that is the cultural aspect. Data were analyzed using qualitative descriptive analysis techniques; and the results are in the form of a creative economic model for MSMEs in Kupang city, Indonesia using bundling product of creative industry; and computer application-based cash flow model.
\end{abstract}

e-ISSN: 2550-7001, p-ISSN: 2550-701X ๑ Copyright 2019. The Author. SS Journals Published by Universidad Técnica de Manabí. This is an open-access article under the CC BY-SA 4.0 license (https://creativecommons.org/licenses/by-sa/4.0/) All rights reserved.

\section{Contents}

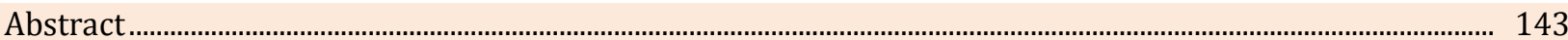

1. Introduction

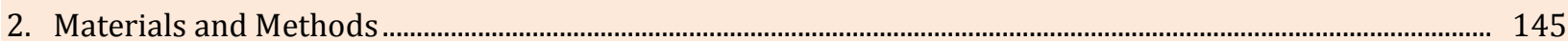

a Business Administration Department, Politeknik Negeri Kupang (Kupang/Indonesia)

b Business Administration Department, Politeknik Negeri Kupang (Kupang/Indonesia) 
3. Results and Discussions ..................................................................................................................................... 146

3.1 Culinary Business Profile in Kupang City …………………………………….............................................. 146

3.2 The Model of Creative Economy Development in the Culinary Industry ..................................................... 147

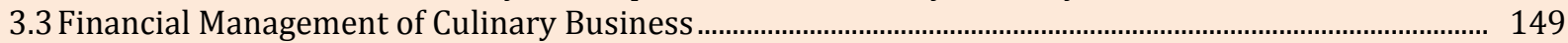

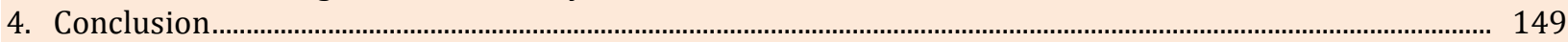

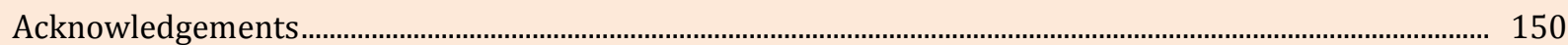

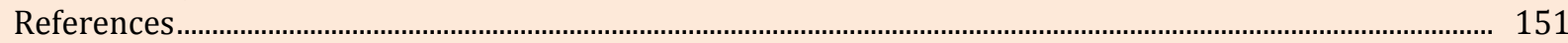

Biography of Authors ......................................................................................................................................... 152

\section{Introduction}

East Nusa Tenggara Province, located in eastern Indonesia, has abundant natural resources, especially in the fisheries, plantation, and agriculture sectors (Kabu \& Tira, 2015; Nino, et al., 2019). These three sectors are sub-sectors of primary human needs, namely food. There are many local natural resources that are exported on a large scale at low prices without further processing. The main point is that creativity for food processing is still needed as a creative economic base for the culinary industry (Agyapong, 2010). Simply, the creative economy is the creation of value-based ideas from the creativity of human resources (creative people) and based on the use of science, including cultural (Cunningham, 2002) and technological heritage (Markusen, 2008). The main resource is creativity, which is defined as the capacity or ability to produce or create something unique, create a solution to a problem or do something different from thinking (the outside box). Creativity is a factor that drives the birth of innovation by utilizing existing inventions (Berry, 2001). According to data derived from the Creative Economy Agency (CEA) of the Republic of Indonesia, the culinary sub-sector contributed 41.4 percent of the total contribution of the creative economy of IDR. 922 trillion in 2016. The amount was the highest compared to 16 other sub-sectors.

The increasing number of outside culinary franchises such as Ayam Brontus, KFC, McDonald, Pizza Hut in several strategic places in Indonesia has a negative impact on the domestic small and medium micro culinary industry (Wijaya, 2016). Some of these culinary franchises have factories in Indonesia, employ Indonesian workers, and obtain raw materials from Indonesia (Vial, 2011). The problem is where the sales will be distributed, namely to countries that have creative ideas in carrying out creative industries. Vial (2011), state that there are as many as 56 million Micro, Small and Medium Enterprises (MSMEs) in Indonesia and 70\% of them are comprised of food MSMEs. Data derived from Central Bureau of Statistics of the Republic of Indonesia shows that industrial production growth (year on year) in Q1 2016 of MSMEs increased in the food industry by $14.76 \%$ and the beverage industry by $13.41 \%$. This is an indicator that the food and beverage industries have great potential to be developed.

The presence of MSMEs in each region is not accompanied by a good management pattern. There are several problems faced by culinary business owners both from external and internal factors (Ghatak, 2011). Problems from internal factors, such as lack of professional management of the organization, lack of mastery of technology and weak marketing, low quality of entrepreneurship, lack of financial / cash-book accounting, investment, less innovative product processing, lack of information, lack of working capital and shortages skilled workforce. While the problems arising from external factors, such as the presence of new competitors, the same substitution products from foreign franchises as a result of ASEAN free trade (Abernethy \& Vagnoni, 2004).

Kupang city as a capital city of East Nusa Tenggara Province in Indonesia has various natural resources such as seaweed, fresh fish, beef, vegetables and so on that have not been utilized optimally (Aliandu, 2015). Therefore, one of the efforts that can be made in maintaining regional economic growth is by optimizing the creative industry as a sector that can increase economic growth (Tepper, 2012). In addition, Kupang City as one of the centers of the creative economy in East Nusa Tenggara Province with a diverse cultural wealth is one of the factors that are able to attract tourists and investors/business people to visit Kupang city. These conditions can encourage the growth of the creative economy which has an impact on the increasing contribution of the creative economy sector to the economic growth of Kupang city (Cooke \&Lazzeretti, 2008).

Based on data obtained from the Regional Investment Coordinating Board (RICB) of Kupang city, in the last three years since 2016, the number of hospitality and culinary businesses has increased rapidly. 67 hotels 
ranging from three-star to jasmine type hotels have 2.658 rooms, 32 homestays, 624 depots and restaurants, and 95 restaurants and cafes. Developments are also seen in other sectors such as fisheries, real estate, and transportation. At present, Kupang city is moving towards the city of trades and services. But the problem here is that many of the small communities in culinary businesses face various limitations such as lack of knowledge and creative ideas in developing their businesses, as well as lack of financial management, such as the absence of standard financial reports, limitations of working capital for business development, limited space and other technical constraints.

In addition, almost $70 \%$ of the culinary industry in Kupang city is dominated by national and even international menus. The problem here is that the native inhabitants of Kupang city have not realized the importance of maintaining regional specialties that are creatively processed into an attractive product both in terms of taste, appearance, and service while maintaining the distinctiveness of local culture. With the distinctiveness of local culinary flavors can be introduced to national and international consumers. Based on preliminary data collected, there are only a few places that provide NTT local specialties, such as Centra UKM C \& A on Frans Seda, Simple Kupang Restaurant, which has experienced a decline in sales turnover and loss of customers since the last few years franchised culinary business outside Kupang city. This is a major concern because to maintain the local culinary MSMEs and introduce menus to domestic and international tourists, it which requires synergy from MSMEs owners of culinary businesses, local government of Kupang city such as the Tourism Office and the Industry and Trade Office of Kupang city, a travel agency and related institutions and entrepreneurs or investors.

Definition of micro, small and medium enterprises according to Indonesian Act No. 20/2008 are presented as follows:

a) Micro businesses are productive businesses owned by individuals and/or individual business entities that have a net worth of at most IDR. 50.000.000 excluding land and buildings for business premises or having annual sales of a maximum of IDR. 300.000.000.

b) Small business is a productive economic enterprise that is independent, carried out by individuals or business entities that are not subsidiaries or not branches of companies. They are owned, controlled, or become part of either directly, or indirectly from medium-sized businesses or large businesses that have net assets more than IDR. 50.000.000 up to a maximum of IDR. 500.000.000 excluding land and buildings for business premises or having annual sales of more than IDR. 300.000.000 up to a maximum of IDR 2.500.000.000.

c) Medium business is a standalone product economic business, carried out by individuals or business entities that are not subsidiaries or branches of companies that are owned, controlled, or become part of either directly or indirectly with small businesses or large businesses that have net assets more than IDR. 500.000.000 up to a maximum of IDR.10.000.000.000 excluding land and buildings for business premises or having annual sales of more than IDR. 2.500.000.000 up to a maximum of IDR. $50,000,000,000$.

The purposes of this study were to 1) identify and map the existence of culinary, and 2) develop a culinary business model based on the creative economy in Kupang city.

\section{Materials and Methods}

The research design used was descriptive qualitative research which is categorized as a case study (O'reilly \& Parker, 2013), focusing on MSMEs in the micro small business industry sector engaged in culinary business in Kupang city. The object of research is MSMEs that are engaged in the culinary business in Kupang city and related agencies. The type of data used in this study is qualitative data sourced from primary data, namely data obtained directly from the object of research. The population in this study were MSMEs Culinary in Kupang city, while the number of samples was determined using a clustering method using purposive sampling technique, which is a sampling technique with certain considerations, where samples were taken based on unique business characteristics and had specificity in based of Creative Economic, namely cultural aspects. The population and sample can be seen in Table 1.

Manteiro, M. C. B., \& Kabu, E. (2019). Model of creative economic development for micro, small and medium-sized culinary industries in Kupang City Indonesia. International Journal of Social Sciences and Humanities, 3(1), 143152. https://doi.org/10.29332/ijssh.v3n1.275 
Table 1

The number of culinary MSMEs in Kupang city

\begin{tabular}{clcc}
\hline No & \multicolumn{1}{c}{ Business Name } & Population Size & Sample Size \\
\hline 1 & CentraUKM C\&A & 6 & 3 \\
2 & Pusat Kuliner Sea Food Kampung Solor & 20 & 5 \\
3 & Aneka jajanan pasar Air Mata & 5 & 3 \\
4 & Jagung bakar El Tari & 12 & 6 \\
5 & Rumah Makan Sederhana & 1 & 1 \\
6 & Ikan Kuah Asam Tenau & 1 & 1 \\
& Total & 45 & 18 \\
\hline
\end{tabular}

Source: Primary data, 2018

Data were collected using the following method:

a) Observations, namely researchers conducted observations to the location of MSME actors to see their business activities.

b) Interview, namely the researcher conducted a question and answer session with the culinary industry SMEs and related government agencies

c) Documentation, namely the researcher collects data relating to the development of the culinary industry.

d) Library study, namely researcher collect data through literature such as journals related to the research title.

The data were analyzed using descriptive methods that systematically described the facts and characteristics of the objects and subjects studied (Kothari, 2004). The research stages in this study were:

a) Analysis of creative economic concepts with relevant research, as well as reviewing and establishing the basic concepts of modeling.

b) Conducting surveys on culinary industries then making maps based on types and business clusters.

c) Analysis of the results of interviews conducted with creative economic actors and related stakeholders.

d) Analysis of the potential for developing creative economy-based culinary industries and map problems both from external and internal faced by culinary entrepreneurs.

e) Preparing a creative economy based MSME development model for the culinary industry.

Preparing a cash flow report application for culinary industry according to the selected cluster

\section{Results and Discussions}

\subsection{Culinary Business Profile in Kupang City}

MSMEs culinary sector has an important role in the economy, both in macro and micro aspects (Siswanto \& Novarena, 2016). In a socio-economic perspective, culinary MSMEs in Kupang city tend to increase along with the increasingly varied consumer demand. In our point of view, culinary services that provide local food in Kupang are increasingly lagging behind because of losing in competing with new culinary or franchise business. Therefore we need a model for developing a creative economy that based on culinary business to sustain the local business. The research was carried out in 6 (six) clusters of the Kupang city. Following table presents the average income of MSMEs Culinary in Kupang City. 
Table 2

Average Income of Culinary City Per Month

\begin{tabular}{cccc}
\hline No & Total income & Respondents & Percentage $(\%)$ \\
\hline 1 & $500-1$ million & 8 & 44.4 \\
2 & $1-3$ million & 5 & 27.7 \\
3 & $3-5$ million & 3 & 16.7 \\
4 & above 5 million & 2 & 11.2 \\
& Total & 18 & 100 \\
\hline
\end{tabular}

Source: Primary data by the author, 2018

From table 2 above, it can be seen that the highest presentation of income is IDR. 500.000 to IDR. 1.000.000. From the management side, the culinary entrepreneurs in Kupang city have not got any financial reports. In the other side, the lowest presentation of income is IDR. 5.000.000. Based on the data, it is known that the businesses have got simple financial reports. The reports are not computer-based applications.

Next, from the 6 selected clusters, the survey results show that creativity and innovation have not been maximized by the entrepreneurs. The following table shows the innovation and creativity of MSMEs in Kupang city.

Table 3

Innovation and Creativity MSMEs in Kupang City

\begin{tabular}{llcccc}
\hline \multirow{2}{*}{ No } & Innovation and Creativity & \multicolumn{3}{c}{ Score } \\
\cline { 3 - 5 } & Almost Never & $\begin{array}{c}\text { Often / } \\
\text { Sometimes }\end{array}$ & Always & Amount (\%) \\
\hline 1 & Menu Presentation & $58 \%$ & $25 \%$ & $17 \%$ & 100 \\
2 & Employee Service & $62 \%$ & $24 \%$ & $14 \%$ & 100 \\
3 & Design of space / place & $67 \%$ & $23 \%$ & $10 \%$ & 100 \\
4 & Use of technology & $70 \%$ & $18 \%$ & $12 \%$ & 100 \\
\hline
\end{tabular}

Source: data that the author is working on, 2018

\subsection{The Model of Creative Economy Development in the Culinary Industry}

Utami \& Lantu (2014) state that one way to develop the business of creative industries in culinary business is from the external side, namely the method of Bundling product and from the internal side, namely strengthening management, especially financial management (application-based). The bundling of the product itself is carrying the strategy by selling two or more products in one package. The purpose of the Bundling product is to increase the guidance among the creative industries sub-sector. This is related to the strategy of getting a multiplier effect from the bundling itself. With this creative economy, bundling will encourage the marketing of other subsectors. Meanwhile from the internal side, strengthening management, especially financial management can help culinary entrepreneurs to be able to manage finances effectively and efficiently, especially in the matters of cash flow statement applications. Next, The Creative Economy model of the Kupang City culinary industry can be seen in the following figure.

Manteiro, M. C. B., \& Kabu, E. (2019). Model of creative economic development for micro, small and medium-sized culinary industries in Kupang City Indonesia. International Journal of Social Sciences and Humanities, 3(1), 143152. https://doi.org/10.29332/ijssh.v3n1.275 


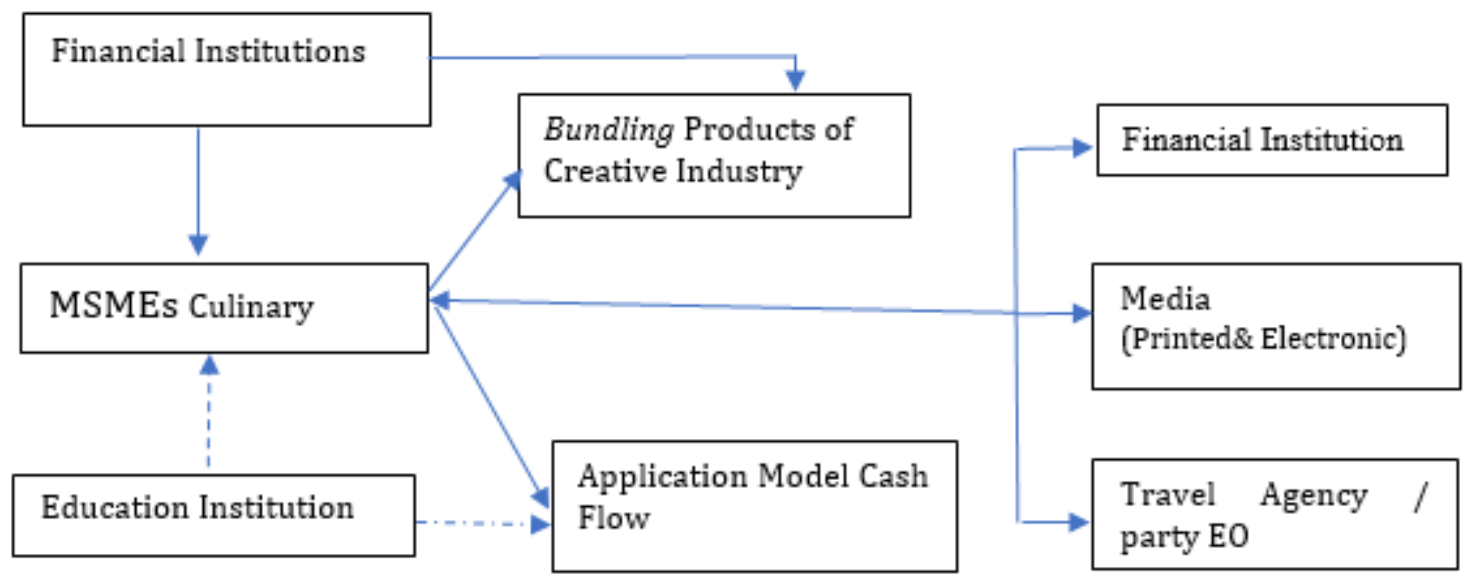

Figure 1. Model of Creative Culinary Industry Development in Kupang City

The external model of creative industry development in Kupang city can be explained through the various roles of supporting institutions below:

\section{1) Media Role (Printed, Electronics, and Promotion Institutions)}

Theoretically, printed and electronic media have a role in informing and promoting creative industries in Kupang City (cf. Hrong \& Tsai, 2012). Some of the creative industries in the city used the printed and electronic media for promoting their business. Based on the research, $20 \%$ of the industries were still lacking in promoting creative economy, $45 \%$ stated that the role is very important while $35 \%$ stated that media has no role in promoting the industry.

Furthermore, our research has shown that the actors of the creative industry expect a special rubric about their business in printed media. They, also, expect a special coverage in electronic media that is to broadcast their business regularly and periodically.

Next, promotion institutions, based on our research, have a role in developing the creative economy. $60 \%$ of creative industry actors have got an opinion that promotion institutions in Kupang city are still lacking in promoting the creative economy. $25 \%$ of the actors state that the institution roles are strong while the rest $15 \%$ state that promotion institutions have no roles.

In addition to printed media (newspapers), electronic media (TV) and promotional institutions, websites, social media (blogs, Facebook and tweeters) are also helpful in promoting products. Furthermore, the current research has shown that outdoor advertising (billboards) is also important to provide information for tourist. The information, as believed, can attract tourists.

\section{2) The Role of Agents (Tourist Travel Agencies)}

Theoretically, agents have a role in developing creative industries, namely in making tour packages or tourist visit locations to culinary places that provide local food (Andersson, 2007). 70\% of creative economic actors have got the opinion that travel agencies are still lacking in promoting the creative economy while $20 \%$ state that the agents have not got any roles. The rest $10 \%$ state that agents have got great roles in promoting the industries.

\section{3) The Role of Financial Institutions}

Institutions have an important role in developing creative industries in Kupang city (Hertzman, 2012). The actors of creative economic have also got the same opinion. Financial institutions can provide funding. In other words, the role of financial institutions is as a provider of funds for the needs of increasing businesses, especially the Culinary MSMEs in Kupang city. 
Based on the current research, $75 \%$ of the creative economic actors state that the financial institution has got an important role, while $23 \%$ of them state that it is not too important. The rest, $12 \%$ state that financial institutions have no role in their business.

\section{4) Role of Kupang City Government}

The role of the government is very important in the development of creative industries in Kupang City (Horng \& Tsai, 2010). Various activities have been carried out by the government to improve the performance of the creative industries, especially the culinary industry. $45 \%$ of creative economic actors state that the role of government is very important in increasing culinary business in Kupang City. $20 \%$ of them state that the role is still lacking, while the $8 \%$ state that Kupang government has no role in developing culinary business.

\subsection{Financial Management of Culinary Business}

Some culinary entrepreneurs in 6 clusters are still not maximal in managing finances. Based on the results of interviews, some of them do not have any standard financial statements. They are still doing manual records. For this reason, we constructed a simple application that is expected to help the actors in making a financial statement that is to know the cash flow turnover of their business (Cole, 1998).

\section{a) The Importance of Cash Flow Reports}

Flow statements are one component of financial statements that are systematically compiled to present information about cash receipts and disbursements within a certain period. The benefits of cash flow reports for small-scale businesses are 1) as a tool to analyze whether the plan in terms of investment or financing has been running as it should; 2) report the mutations of cash in and out of cash for a certain period of time; 3 ) provide useful information about the company's ability to generate cash from operating activities, make investments, pay off obligations or for the personal needs of the owner. Thus, through the direct method cash flow statement, the owner or manager can easily find out the type and amount of cash receipts and disbursements from operational activities, investments and financing/funding.

\section{b) Modeling of Cash Flow Reports Cash}

Flow statement modeling in the current study used the direct method. In this way, each transaction related to cash receipts and expenses is immediately identified and displayed in the cash flow statement. For this purpose, it is first necessary to design a special journal that can automatically identify and classify the types of transactions related to cash by using the Microsoft Excel formulas. Based on the results of interviews with culinary service business actors, the types of business transactions that occur include the purchase of raw materials for the manufacture of various foods and beverages. Transactions that are directly related to cash flow statements consist of cash receipt transactions from deposits/addition of owner's capital, cash disbursement to purchase raw materials for making food and beverages, payment of transportation, payment of workers' wages, cash outlays to pay for operational costs (electricity, telephone/communication and water accounts) and taxes, cash receipts from cash sales, cash receipts from credit sales, cash disbursements for installments/loan installments, and price.

\section{Conclusion}

In this section, we provide conclusions and some suggestions related to the current research. There are four points of conclusions. Firstly, the 6 selected cluster regions in Kupang city, Indonesia are prospective enough to be developed with the Creative Economy Development Model in terms of industry aspects, technological aspects, resource aspects, institutional aspects and aspects of financial institutions. The clusters are in a high category and have a great opportunity to develop and become a model for culinary business development and regional economic base in Kupang City.

Secondly, the problems faced by culinary business owners in the selected clusters are quite diverse, including the lack of cooperation with other economic institutions and the government so that culinary MSMEs that sell NTT local food are not known or are still unable to compete with culinary businesses that come from outside the Kupang city.

Manteiro, M. C. B., \& Kabu, E. (2019). Model of creative economic development for micro, small and medium-sized culinary industries in Kupang City Indonesia. International Journal of Social Sciences and Humanities, 3(1), 143152. https://doi.org/10.29332/ijssh.v3n1.275 
Thirdly, the model of Bouding Product in the creative economy industry is expected to help the MSMEs culinary industry in developing small businesses. Fourthly, in management matter, especially in financial management, application model for cash flow is made for facilitating entrepreneurs of small culinary businesses in Kupang city, Indonesia to well-record their business transactions and to prepare the financial statement timely.

Based on the discussion as well as the conclusions that have been made above, we suggest four main points. The first, the entrepreneurs of local culinary MSMEs in Kupang city Indonesia is hoped to be able to maintain their business by increasing their creativity and innovation without eliminating the distinctiveness of local menus of eastern Indonesia. The second, for the government and the economic creative institutions in the city, they are hoped to establish cooperation so that there will be a synergy for the progress and prosperity of the people of Kupang city, especially in the creative industries of the local Culinary. The third, travel agent entrepreneurs and event organizers entrepreneurs are hoped to be build cooperation with local culinary MSMEs by involving culinary entrepreneurs in culinary tour packages, for both domestic and foreign tourists as well as for local/national events that held at Kupang city, Indonesia. The last, for future researchers, it is hoped they can develop models of this study by looking at and examining the other factors in the creative industry of Indonesia.

\section{Acknowledgments}

This work was supported by the Research Fund provided by Politeknik Negeri Kupang. Therefore, we would like to offer our thanks to the director of Politeknik Negeri Kupang. 
References

Abernethy, M. A., \& Vagnoni, E. (2004). Power, organization design and managerial behaviour. Accounting, Organizations and Society, 29(3-4), 207-225. https://doi.org/10.1016/S0361-3682(03)00049-7

Andersson, T. D. (2007). The tourist in the experience economy. Scandinavian journal of hospitality and tourism, 7(1), 46-58. https://doi.org/10.1080/15022250701224035

Agyapong, D. (2010). Micro, small and medium enterprises' activities, income level and poverty reduction in ghana-A synthesis of related literature. International Journal of Business and Management, 5(12), 196.

Aliandu, P. (2015). Sentiment analysis to determine accommodation, shopping and culinary location on foursquare in Kupang City. Procedia Computer Science, 72, 300-305.

Berry, A., Rodriguez, E., \& Sandee, H. (2001). Small and medium enterprise dynamics in Indonesia. Bulletin of Indonesian Economic Studies, 37(3), 363-384.

Cooke, P. N., \& Lazzeretti, L. (Eds.). (2008). Creative cities, cultural clusters and local economic development. Edward Elgar Publishing.Cole, D., Cole, D. C., \& Slade, B. F. (1998). Building a modern financial system: The Indonesian experience. Cambridge University Press.

Cunningham, S. (2002). From cultural to creative industries: theory, industry and policy implications. Media International Australia incorporating Culture and Policy, 102(1), 54-65.

Ghatak, S. (2010). Micro, small and medium enterprises (MSMEs) in India: an appraisal. Journal of EOFEMD, 2(5), 1-19.

Hertzman, J. L., \& Maas, J. (2012). The value of culinary education: Evaluating educational costs, job placement outcomes, and satisfaction with value of associate degree culinary and baking arts program graduates. Journal of culinary science \& technology, 10(1), 53-74.

Horng, J. S., \& Tsai, C. T. (2012). Culinary tourism strategic development: an Asia-Pacific perspective. International journal of tourism research, 14(1), 40-55. Doi: https://doi.org/10.1016/j.tourman.2009.01.009

Horng, J. S., \& Tsai, C. T. S. (2010). Government websites for promoting East Asian culinary tourism: A crossnational analysis. Tourism management, 31(1), 74-85. Doi: https://doi.org/10.1002/jtr.834

Kabu, E., \& Tira, D. S. (2015). Value Chain Analysis Towards Sustainability: A Case Study of Fishery Business in Kota Kupang, Indonesia. International Journal of Economics and Financial Issues, 5(1S), 150-156.

Markusen, A., Wassall, G. H., DeNatale, D., \& Cohen, R. (2008). Defining the Creative Economy: Industry and Occupational Approaches. Economic Development Quarterly, 22(1), 24-45. https://doi.org/10.1177/0891242407311862

Nino, I. J., Manafe, J. D., \& Setyorini, T. (2019). Simple bookkeeping model using Microsoft excel for culinary micro-business in East Nusa Tenggara Indonesia. International research journal of engineering, IT \& scientific research, 5(2), 29-41. https://doi.org/10.21744/irjeis.v5n2.609

O'reilly, M., \& Parker, N. (2013). 'Unsatisfactory Saturation': a critical exploration of the notion of saturated sample sizes in qualitative research. Qualitative research, 13(2), 190-197.

Siswanto, J., \& Novarena, N. S. (2016). Identification of business system based on business process of small culinary enterprises. In 2016 International Conference on Information Technology Systems and Innovation (ICITSI) (pp. 1-8). IEEE.

Tepper, S. J. (2002). Creative assets and the changing economy. The Journal of Arts Management, Law, and Society, 32(2), 159-168.

Utami, R. M., \& Lantu, D. C. (2014). Development competitiveness model for small-medium enterprises among the creative industry in bandung. Procedia-Social and Behavioral Sciences, 115, 305-323.Kothari, C. R. (2004). Research methodology: Methods and techniques. New Age International.

Vial, V. (2011). Micro-entrepreneurship in a hostile environment: evidence from Indonesia. Bulletin of Indonesian Economic Studies, 47(2), 233-262.

Wijaya, S., Morrison, A., Nguyen, T. H., \& King, B. (2016). Exploration of Culinary Tourism in Indonesia: What Do the International Visitors Expect?. In Asia Tourism Forum 2016-the 12th Biennial Conference of Hospitality and Tourism Industry in Asia. Atlantis Press. https://doi.org/10.2991/atf-16.2016.56

Manteiro, M. C. B., \& Kabu, E. (2019). Model of creative economic development for micro, small and medium-sized culinary industries in Kupang City Indonesia. International Journal of Social Sciences and Humanities, 3(1), 143152. https://doi.org/10.29332/ijssh.v3n1.275 


\section{Biography of Authors}

\begin{tabular}{||l|l||}
\hline Maria C. B. Manteiro is a senior lecturer in Politeknik Negeri Kupang, Indonesia. \\
Besides teaching, she is active in conducting researches. Some of her researches \\
have been published in both National Journals and International Journals. She, \\
currently, is interested in creative economic fields \\
Email: chendymanteiro6@gmail.com
\end{tabular}

